\title{
Intellectual capital disclosure practices of financial institutions in an emerging economy
}

\author{
Credit Rating Information and Services Limited (CRISL), Dhaka, Bangladesh, and \\ Alima Aktar \\ Department of Management, North South University, Dhaka, Bangladesh
}

\begin{abstract}
Purpose - The purpose of this study is to investigate the intellectual capital disclosure (ICD) practices of financial institutions in an emerging economy of Bangladesh.

Design/methodology/approach - Based on 93 items of intellectual capital categorized into internal capital, external capital and human capital, ICD index is developed for 53 financial institutions listed in Dhaka Stock Exchange. This study uses descriptive statistics to analyze ICD practices, and parametric and nonparametric tests to analyze the variation of ICD practices in terms of different categories as well as in terms of different sectors.

Findings - Results indicate that more than $70 \%$ of ICD items are generally not disclosed by financial institutions in Bangladesh. The highest of 36\% of external capital disclosure items are disclosed, whereas the lowest of $18 \%$ of human resource capital elements are disclosed. Furthermore, results find the significant variability of ICD practices in terms of different intellectual capital categories and in between banking companies and non-banking financial institutions.

Practical implications - Findings have critical implications for managers, policymakers and regulators for setting appropriate strategies and regulations for improving the level of ICD, which, in turn, may reduce the information asymmetry problems of financial institutions as well.

Originality/value - In-depth analysis about variability of ICD practices creates value in the ICD literature by highlighting strategic priority of financial institutions to disclose information about the strategic resources in unique emerging economic settings such as Bangladesh.
\end{abstract}

Keywords Emerging economy, Intellectual capital, Human capital, Financial institutions,

Disclosure strategy, Intellectual capital disclosure index

Paper type Research paper

\section{Introduction}

This study investigates the intellectual capital disclosure (ICD) practices of financial institutions in Bangladesh. The level and variation of ICD in terms of company, sector and disclosure categories are analyzed under the premise that companies disclose intellectual capital information to improve transparency to stakeholders (McPhail, 2009). Information

(C) Syed Abdulla Al Mamun and Alima Aktar. Published in PSU Research Review. Published by Emerald Publishing Limited. This article is published under the Creative Commons Attribution (CC BY 4.0) licence. Anyone may reproduce, distribute, translate and create derivative works of this article (for both commercial and non-commercial purposes), subject to full attribution to the original publication and authors. The full terms of this licence maybe seen at http://creativecommons.org/ licences/by/4.0/legalcode

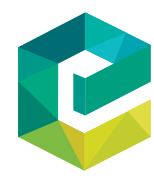


PRR

5,1

asymmetry is the inherent problem for companies because of the separation of its ownership and management, which also known as agency problem. These problems are more acute in an emerging economy such as Bangladesh which is characterized with weaker legal and institutional environment compared to developed economies. For this reason, shareholders along with other stakeholders struggle for credible and timely information which are essential to make informed decisions. Typically, the key purposes of disclosing material information in the annual report of a company are to mitigate the information asymmetry problem, and assist all types of stakeholders to make prudent decisions so that their interests can be protected. As the traditional economy is gradually shifting into knowledgebased economy, information about intellectual capital (IC) is the key to understand the competitive advantage of a company (Burgman and Roos, 2007; Stewart, 1997). IC refers to the intangible assets that an organization can use to create value by converting it into new process, products and services (Guthrie et al., 2006). According to Bollen et al. (2005), though IC is not presented in the corporate balance sheet such as other traditional assets, it is considered as the strategic asset which plays the critical role in achieving competitive advantages and creating corporate value. Therefore, disclosure about IC information is treated as one of the means of improving transparency by reducing information asymmetry problem between management and other corporate stakeholders (Johanson, 2003).

According to Abeysekera (2006), knowledge-intensive companies depend more on IC rather than other balance sheet assets to create value. Consequently, IC plays an important role in achieving the sustainable performance of the knowledge-based companies such as financial institutions. Because Bangladesh is a bank-based economy, Bangladeshi companies significantly rely on financial institutions to generate their capital. Moreover, the GDP contribution of the service sector has doubled in Bangladesh in the past four decades. Financial industry is one of the major service sectors of Bangladesh, which not only supports to create capital but also involves in economic transactions and employment generation. Thus, it is noteworthy to understand the state of IC of the financial institutions in Bangladesh. The disclosure of IC information can enhance profitability of a company by reducing cost of capital (Bismuth and Tojo, 2008; Dumay, 2012). In addition, because the well accepted valuation approach for IC is yet to develop, this study concentrates on the disclosure of IC information in annual reports for deepening the understanding about ICD practices in financial institutions of Bangladesh.

Most of the previous studies (Ahmed Haji and MohdGhazali, 2013; Whiting and Woodcock, 2011; Atan and Rahim, 2012; Ousama et al., 2012; Ferreira et al., 2012; Taliyang et al., 2011) exclude financial institutions from their sample with the excuse of distinctive characteristics of financial institutions in terms of higher level of regulation. Similarly, prior studies (Abhayawansa and Azim, 2014; Rahman et al., 2019; Nurunnabi and Hossain, 2011; Dey and Faruq, 2019) in the context of Bangladesh mostly focused on non-financial companies. However, as per the legal and regulatory requirements, it is not mandatory to disclose ICD for the financial institutions of Bangladesh. Indeed, the level of ICD practices depends on strategic preference of companies (Slack and Munz, 2016) regardless of its nature of industry. In addition, although studies by Khan and Ali (2010) and Belal et al. (2018) investigated the ICD practices of banks in Bangladesh, none of the prior studies considered non-banking financial institutions (NBFI) for investigating ICD practices. Therefore, the current study attempts to investigate the ICD practices of financial institutions, including both banks and NBFIs of Bangladesh. This study considers 30 banks and 23 NBFIs listed in Dhaka Stock Exchange (DSE) to develop ICD index based on 93 items of intellectual capital in line with the study of Ousama and Fatima (2012). Descriptive analysis, parametric tests and non-parametric tests are used to analyze the ICD scores of 
these companies to investigate the ICD practices. Findings of this study enrich the literature of ICD by providing deep insights about the tendency and strategic priorities of financial institutions for adopting their ICD practices. In addition, unlike prior studies (Khan and Ali (2010), Nurunnabi and Hossain, 2011; Abhayawansa and Azim, 2014; Belal et al., 2018; Dey and Faruq, 2019; Rahman et al., 2019) in the context of Bangladesh, the current study extends the ICD literature with the empirical findings about the variability of ICD practices between the sub-sectors of financial industry.

All listed banks and NBFIs are under the regulation of the central bank, namely, Bangladesh Bank and stock market regulator, namely, Bangladesh Securities and Exchange Commission (BSEC). The nature and extent of disclosure of listed financial institutions of Bangladesh are directed by Securities and Exchange (SEC) Rules 1987, the Companies Act 1994, Banking Companies Act 1991 Financial Institution Act 1993, Bangladesh Accounting Standards (BASs), Bangladesh Financial Reporting Standards (BFRSs), Financial Reporting Act (FRA) 2015 and Income Tax Ordinance 1984.

\section{Literature review and hypothesis development}

\subsection{Intellectual capital and intellectual capital disclosure}

In spite of growing importance of IC to managers and researchers, well-accepted definition of IC is yet to be found in extant literature. Different scholars attempt to define IC from different perspectives ranging from a subset of intangible capital (Hunter et al., 2005), the difference between the market value and the book value of a firm (Ordonez de Pablos, 2005) and knowledge-based resources that contribute to the creation of a competitive advantage for the firm (Ordonez de Pablos, 2005). This study considers the more comprehensive perspective of IC, which is composition of all knowledge-based intangible assets and processes, which are not normally shown on the balance sheet, and can be leveraged to give rise to future value (Roos et al., 1997). Under the tenet of tripartite concept, a good number of prior research studies of ICD (Petty and Cuganesan, 2005) have been found in the literature. These studies are primarily grounded by Erik Sveiby (1997) suggesting three types of capital such as internal, external and human capital. These three components of IC have been further divided into a number of sub-categories (Gray, 2013) which varied from 18 to 25 as observed in different prior studies. Table 1 presents 25 sub-categories of three components of IC as per the study by Ousama et al. (2011), which are primarily considered in this current study for exploring the ICD practices.

In a knowledge-intensive business environment, the corporate value depends not only on production of physical goods but also on the creation and utilization of IC (Guthrie et al., 2004). However, the prevailing accounting framework and accounting standards do not allow a full recognition and disclosure of IC components in financial statements (Van der Meer-Kooistra and Zijlstra, 2001). In addition, there is no specific guideline or regulation for the reporting of IC information in the corporate annual reports (Brüggen et al., 2009). Moreover, because it is difficult to standardize soft intangible assets (Lambert, 1998), Grojer and Johanson (1999) have advocated for the voluntary standard for the ICD in the context of rapid change of IC. In Bangladesh, there is no mandatory requirement or guideline for the ICD in the annual reports of the financial institutions. This current study, therefore, considers IC data disclosure as the voluntary strategic choice of individual companies.

\subsection{Hypotheses development}

2.2.1 Intellectual capital disclosure practices. Typically, the disclosing of IC information in the annual reports is voluntary for the firms. Prior studies, therefore, have found that level of ICD of the firms in emerging economies is lower than firms from developed economies. More
Intellectual capital disclosure practices 


\begin{tabular}{|c|c|c|c|}
\hline & & & \\
\hline PRR & 1. Internal capital & 2. External capital & 3. Human capital \\
\hline & 1.1 Innovations & $\begin{array}{l}2.1 \text { Business partnering } \\
\text { and alliances agreements }\end{array}$ & 3.1 Gender of employees \\
\hline & 1.2 Technological infrastructure & $\begin{array}{l}2.2 \text { Goodwill acquired in } \\
\text { business combinations }\end{array}$ & 3.2 Age of the employees \\
\hline 36 & 1.3 Technology investment & $\begin{array}{l}\text { 2.3 Separately acquired } \\
\text { intangible assets }\end{array}$ & 3.3 Education level \\
\hline & $\begin{array}{l}\text { 1.4 Research and development } \\
\text { 1.5 Other internally generated } \\
\text { intangible assets }\end{array}$ & $\begin{array}{l}2.4 \text { Loyalty } \\
2.5 \text { Customer satisfaction }\end{array}$ & $\begin{array}{l}\text { 3.4 Flexibility } \\
\text { 3.5 Employee welfare }\end{array}$ \\
\hline & $\begin{array}{l}\text { 1.6 Quality } \\
\text { 1.7 Communication systems }\end{array}$ & $\begin{array}{l}\text { 2.6 Customers } \\
\text { 2.7 Suppliers }\end{array}$ & $\begin{array}{l}\text { 3.6 Training and education } \\
\text { 3.7 Participation in the development of } \\
\text { the company }\end{array}$ \\
\hline & $\begin{array}{l}\text { 1.8 Processes } \\
\text { 1.9 Problem-solving capacity }\end{array}$ & $\begin{array}{l}\text { 2.8 Marketing } \\
\text { 2.9 Turnover and } \\
\text { distribution channels }\end{array}$ & $\begin{array}{l}\text { 3.8 Knowledge map } \\
\text { 3.9 Employee satisfaction }\end{array}$ \\
\hline & 1.10 Management philosophy & $\begin{array}{l}2.10 \text { Market value and } \\
\text { share price }\end{array}$ & 3.10 Employee evaluation \\
\hline $\begin{array}{l}\text { Table } 1 \text {. } \\
\text { ICD indicators used } \\
\text { by Ousama et al. } \\
\text { (2011) }\end{array}$ & & 2.11 Shareholders & $\begin{array}{l}\text { 3.11 Distribution of employees } \\
\text { 3.12 Employee capacities and abilities } \\
\text { 3.13 Employee development plans } \\
\text { 3.14 Safety and health of employees }\end{array}$ \\
\hline
\end{tabular}

specifically, existing evidence from the emerging economies shows that the level of ICD is below 50\%. For example, Ahmed Haji and MohdGhazali (2013) have studied 60 top Malaysian companies as per market capitalization and found that only $42 \%$ of IC information has been disclosed by the top firms. Similar results have also been found by Ousama and Fatima (2012), Singh and Kansal (2011), etc. That means, firms from emerging economies are reluctant to disclose IC information in their annual reports. Moreover, though the financial institutions are highly regulated industry in Bangladesh, there is no mandatory requirement to disclose the IC information in their annual reports. In addition, a study by Khan and Ali (2010) on the banks in Bangladesh shows that only 29\% out of 21 IC information are disclosed in the annual reports of the banks. Therefore, the current study hypothesizes that most of the items of ICD are undisclosed in the annual reports of the financial institutions in Bangladesh. In other words, the level of disclosure is low or poor in the companies:

H1. The level of ICD is low in the annual reports of financial institutions of Bangladesh.

2.2.2 Variation of different categories of intellectual capital disclosure. Striukova et al. (2008) observed that companies from different knowledge-intensive industries do not give the balanced focus on different categories of ICD. Other prior studies (Guthrie et al., 2012; Khan and Ali, 2010; Bozzolan et al., 2006; Abeysekera and Guthrie, 2005, etc.) also demonstrated the similar findings that companies are varied to prioritize in disclosing different categories of IC information. Moreover, the priority of ICD categories changes over time in the same context. For example, though Wagiciengo and Belal (2012) found that HC is the mostly disclosed ICD category in the South African context, another study in the same context by April et al. (2003) found external capital is the highest ICD category. In fact, prior studies not only provided the evidence of variation of different ICD categories, but also indicated the inconsistency in prioritizing an ICD category. These inconclusive aspects of prior findings 
lead to another hypothesis, i.e. financial institutions in Bangladesh may have different emphasis on three different IC categories to disclose information in their annual reports:

H2. The levels of disclosure for three categories of IC, i.e. internal capital disclosure (INCD), external capital disclosure (EXCD) and human capital disclosure (HCD) are varied in the financial institutions of Bangladesh.

2.2.3 Variation of intellectual capital disclosure practices by sectors. Bozzolan et al. (2003) conducted a research on different companies that are listed in Italian Stock Exchange, and found that the extent of IC information documentation depends on the type of industry a company belongs to. Similar results were observed by Whiting and Woodcock (2011), who concluded that IC-intensive firms intend to disclose more IC because of their limited physical assets on which they could report. These findings also support the legitimacy theory which argues that firms with higher IC have no option but to disclose information about their IC to satisfy their stakeholders. In contrast, Oliveira et al. (2010) did not find significant impact of the IC intensity of a firm on the extent of the ICD. Nevertheless, Striukova et al. (2008) pointed out the variation of the level of ICD and its different categories within different knowledge-based sectors. Moreover, information asymmetry problem can be varied among different sectors because of the diversity of nature and intensity of agency conflict among them. Though both banking sector and NBFI sector are highly knowledge-based or IC intensive, this study, therefore, expects the differences of the level of ICD between these two IC-intensive sectors. Therefore, based on the agency theory, the third hypothesis of this study is as follows:

H3. The level of ICD is varied between two sub-sectors of financial industry, i.e. banks and NBFI of Bangladesh.

$H 3 a$. There is a variation of level of INCD between banks and NBFI of Bangladesh.

H3b. There is a variation of level of EXCD between banks and NBFI of Bangladesh.

$H 3 c$. There is a variation of level of HCD between banks and NBFI of Bangladesh.

\section{Methodology}

\subsection{Sample and data}

There are 100 listed financial institution in DSE, comprising 30 banks, 23 NBFIs and 47 insurance companies. The current study considers 53 financial institutions, except insurance companies that are listed in DSE. As the nature of operation and regulatory authority of insurance companies in Bangladesh are different than those of the banks and NBFIs, this study exclusively focuses on only the listed banks and NBIFs to analyze their ICD practices. The data regarding ICD of the sample companies are collected from their published annual reports for year 2014. A listed company is deemed not to have followed a practice if it is not clearly stated in the annual report. Because the annual report is the primary medium of communication between the company and its stakeholders, all important matters about a company should be fully disclosed.

\subsection{Measurement of intellectual capital disclosure}

As there is no generally accepted model for selecting items of disclosure construct disclosure index to measure the quality of disclosure (Beattie and Thomson, 2007), this study considers a disclosure checklist promulgated by Ousama et al. (2011) to develop the ICD index for
Intellectual capital disclosure practices

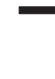


PRR

5,1

38

sample companies. To date, this is the most comprehensive ICD index comprising 101 IC information items summarized based on the prior disclosure literature (Ousama and Fatima, 2012). The current study uses 93 items (see Appendix), which are relevant and are required to be disclosed by the financial institutions in their annual reports. For example, ICD items related to "goodwill acquired in the business combination" are not relevant in this context, and no such business incident is experienced by the sample financial institutions for the period. Selected 93 items were categorized into three different categories of information, such as internal capital: INC (36 items), external capital: EXC (22 items) and human capital: $\mathrm{HC}$ (35 items).

The study constructs an intellectual capital disclosure index (ICDI) for each sample financial institution to measure its level of ICD practices. A dichotomous approach was used to conduct the survey, where each company was awarded a score of " 1 " if the company appears to have disclosed the concerned reporting variable and " 0 " otherwise. The score of each company was totaled to find the net score of the company. An un-weighted ICDI was then computed by using the following formula:

$$
I C D=\frac{\text { Total ICD score of individual company }}{\text { Maximum possibble score obtainable, i.e.93 }}
$$

The disclosure index for the three IC categories [internal capital disclosure index (INCDI), external capital disclosure index (EXCDI) and human capital disclosure index (HCDI)] is also developed in the same way.

\subsection{Data analysis}

This study uses descriptive analysis for explaining the ICD practices by the financial institutions of Bangladesh. To analyze the differences of ICD by its categories and by the sectors, the study relies on both parametric and non-parametric tests because of the problem of normality of the data distribution specifically for each category of IC information.

\section{Findings and discussion}

\subsection{Intellectual capital disclosure practices}

4.1.1 Intellectual capital disclosures by financial institutions. Table 2 shows the results of descriptive analysis of the ICDI for overall financial institutions and for the banking sector and NBFI sector. Overall results represent that the mean score of ICDI is 0.28 , which indicates the level of ICD of listed financial institutions in Bangladesh is $28 \%$. In other words, the financial institutions in Bangladesh, on average, disclose $28 \%$ items out of 93 ICD items, considered to formulate ICDI, in their annual reports, which indicates the poor level of ICD compared to the expected disclosure level. Primarily, this result suggests that

Table 2.

Descriptive statistics of ICD index by financial institutions

\begin{tabular}{lccccccccccccc}
\hline & \multicolumn{4}{c}{ Overall } & \multicolumn{1}{c}{ Bank } & \multicolumn{4}{c}{ NBFI } \\
Items & INCDI & EXCDI & HCDI & ICDI & INCDI & EXCDI & HCDI & ICDI & INCDI & EXCDI & HCDI & ICDI \\
\hline Mean & 0.34 & 0.36 & 0.18 & 0.28 & 0.39 & 0.36 & 0.20 & 0.31 & 0.27 & 0.35 & 0.14 & 0.24 \\
Median & 0.36 & 0.36 & 0.14 & 0.28 & 0.39 & 0.36 & 0.20 & 0.32 & 0.25 & 0.32 & 0.11 & 0.24 \\
SD & 0.13 & 0.05 & 0.09 & 0.08 & 0.11 & 0.05 & 0.09 & 0.07 & 0.12 & 0.06 & 0.08 & 0.08 \\
Min & 0.11 & 0.27 & 0.03 & 0.14 & 0.17 & 0.27 & 0.09 & 0.18 & 0.11 & 0.27 & 0.03 & 0.14 \\
Max & 0.69 & 0.50 & 0.43 & 0.43 & 0.69 & 0.50 & 0.43 & 0.43 & 0.47 & 0.50 & 0.34 & 0.43 \\
Std. error & 0.02 & 0.01 & 0.01 & 0.01 & 0.02 & 0.01 & 0.02 & 0.01 & 0.02 & 0.01 & 0.02 & 0.02 \\
\hline
\end{tabular}


the financial industry, a highly IC-based industry, of Bangladesh is very conservative in disclosing the IC information.

The finding of this study is consistent with a prior study on ICD of banking industry in Bangladesh by Khan and Ali (2010) and Belal et al. (2018). However, a comparison of the findings of the current study with some other prior studies highlights some inconsistency as well. More specifically, the extent of ICD of the current study is higher than some prior studies (Ousama and Fatima, 2012; Singh and Kansal, 2011; White et al., 2007), and lower than the level of ICD found by another set of prior studies such as Soon Yau et al. (2009), Omar (2008), Li et al. (2008) and Bozzolan et al. (2003). The possible five reasons for these inconsistent results are as follows: first, the different studies used different set of ICD items with different numbers; second, these studies focused on various types of industries; third, the sample size of different studies was varied; fourth, these studies are conducted in different time periods and, finally, in different economic context or countries.

Overall results in Table 2, further, demonstrate that the level of EXCD $(36 \%)$ is highest as compared to INCD (34\%) and HCD (18\%). The results of the highest level of EXCD is consistent with most of the prior studies (Ousama and Fatima, 2012; Khan and Ali, 2010; Striukova et al., 2008), which found that EXC was the highest disclosed IC category in the annual reports of the companies. These results suggest that listed financial institutions in Bangladesh disclose, on average, more IC information in terms of EXC category as compared to the INC and HC. However, the results of ICD categories of the banking industry indicate that the disclosure level of INCD (39\%) is highest among all three IC categories by the banks in Bangladesh, which is consistent with the results of the study by Bhatia and Mehrotra (2016) on Indian banks. Similar findings can be observed in the studies of Rahman et al. (2019) and Singh and Kansal (2011) that the INC is the highest ICD category for pharmaceutical companies in the context of Bangladesh as well as India, respectively.

Table 2 also shows that level of ICD in banking sector is higher than NBFI in terms of ICD ( $31 \%$ and $24 \%)$ and its three sub-categories, i.e. INCD (39\% and 27\%), EXCD (36\% and $35 \%)$ and $\mathrm{HCD}(20 \%$ and $14 \%)$. These results are consistent with findings of some prior studies such as Striukova et al. (2008), Petty et al. (2009) and Bozzolan et al. (2006), which also support the role of respective sectors for the level of ICD of companies.

In brief, the findings presented in Table 5 indicate that level of ICD is very low in terms of overall sample of financial institutions as well as for each sector, as $70 \%-75 \%$ of items of ICD information remained undisclosed in the annual reports of the listed financial institutions in emerging economy such as Bangladesh. These results initially support $H 1$, which is consistent with a prior study by Khan and Ali (2010) as well. In addition, results of this study highlight the sign of variation of ICD not only by sectors, i.e. bank and NBFI, but also by ICD categories. The following parts, therefore, focus on deeper analysis and discussion about these variations of ICD and examine the significance level of the differences.

4.1.2 Intellectual capital disclosures by sub-categories of disclosure. Table 3 presents the extended analysis of the ICD disclosure by the different sub-categories of each ICD category and their respective ranking based on the level of disclosure by listed financial institutions in Bangladesh. Out of total 33 sub-categories, INC comprises 10 sub-categories, EXC consists of 9 sub-categories and $\mathrm{HC}$ holds 14 sub-categories. Results of the overall ranking in the table shows that the "management philosophy", under INC category, with the average score of 0.96 , is top among all 33 sub-categories of ICD, suggesting that $96 \%$ of sample companies are disclosing information about their management philosophy in annual reports. In addition, 95\% of the companies are disclosing information about the "market value and share price", which is a sub-category of EXC. On the other hand, none of the 


\section{PRR}

5,1
ICD elements

Bank

Mean Rank Mean Rank Mean Rank Overall rank
Internal capital (INC)

1.1 Innovations

1.2 Technological infrastructure

40

1.3 Technology investment
1.4 Research and development

1.5 Other internally generated intangible assets

1.6 Quality

1.7 Communication systems

1.8 Processes

1.9 Problem-solving capacity

1.10 Management philosophy

\section{External capital (EXC)}

2.1 Business partnering and alliances agreements 2.2 Loyalty

2.3 Customers' satisfaction

2.4 Customers

2.5 Suppliers

2.6 Marketing

2.7 Turnover and distribution channels

2.8 Market value and share price

2.9 Shareholders

\section{Human capital (HC)}

3.1 Gender of employees

3.2 Age of the employees

3.3 Education level

3.4 Flexibility

3.5 Employees' welfare

3.6 Training and education

3.7 Participation in the development of the company

3.8 Knowledge map

Table 3.

Descriptive statistics of intellectual capital disclosure by subcategories
3.9 Employees' satisfaction

3.10 Employees' evaluation

3.11 Distribution of employees

3.12 Employees' capacities and abilities

3.13 Employee development plans

3.14 Safety and health of employees

$\begin{array}{rrrrrrr}0.50 & 4 & 0.39 & 3 & 0.45 & 3 & 9 \\ 0.51 & 3 & 0.43 & 2 & 0.48 & 2 & 6 \\ 0.40 & 5 & 0.17 & 7 & 0.30 & 6 & 14 \\ 0.56 & 2 & 0.29 & 5 & 0.44 & 4 & 10 \\ 0.30 & 7 & 0.26 & 6 & 0.28 & 7 & 15 \\ 0.12 & 9 & 0.07 & 9 & 0.10 & 9 & 23 \\ 0.32 & 6 & 0.29 & 4 & 0.31 & 5 & 13 \\ 0.22 & 8 & 0.15 & 8 & 0.19 & 8 & 18 \\ 0.00 & 10 & 0.00 & 10 & 0.00 & 10 & 27 \\ 1.00 & 1 & 0.91 & 1 & 0.96 & 1 & 1\end{array}$

$\begin{array}{rrrrrrr}0.67 & 2 & 0.59 & 3 & 0.63 & 3 & 4 \\ 0.00 & 8 & 0.00 & 8 & 0.00 & 8 & 27 \\ 0.12 & 6 & 0.09 & 6 & 0.10 & 6 & 21 \\ 0.16 & 5 & 0.07 & 7 & 0.12 & 5 & 20 \\ 0.00 & 8 & 0.00 & 8 & 0.00 & 8 & 27 \\ 0.50 & 4 & 0.50 & 4 & 0.50 & 4 & 5 \\ 0.05 & 7 & 0.13 & 5 & 0.08 & 7 & 25 \\ 0.97 & 1 & 0.94 & 1 & 0.95 & 1 & 2 \\ 0.67 & 2 & 0.68 & 2 & 0.67 & 2 & 3\end{array}$

$\begin{array}{lllllll}0.17 & 7 & 0.13 & 7 & 0.15 & 7 & 19\end{array}$

$\begin{array}{lllllll}0.10 & 8 & 0.09 & 9 & 0.09 & 9 & 24\end{array}$

$\begin{array}{lllllll}0.50 & 2 & 0.43 & 1 & 0.47 & 1 & 7\end{array}$

$\begin{array}{lllllll}0.00 & 11 & 0.00 & 11 & 0.00 & 11 & 27\end{array}$

$\begin{array}{rrrrrrr}0.10 & 8 & 0.11 & 8 & 0.10 & 8 & 21\end{array}$

$\begin{array}{lllllll}0.25 & 5 & 0.14 & 6 & 0.20 & 6 & 17\end{array}$

$\begin{array}{lllllll}0.00 & 11 & 0.00 & 11 & 0.00 & 11 & 27\end{array}$

$\begin{array}{lllllll}0.00 & 11 & 0.00 & 11 & 0.00 & 11 & 27\end{array}$

$\begin{array}{lllllll}0.00 & 11 & 0.00 & 11 & 0.00 & 11 & 27\end{array}$

$\begin{array}{lllllll}0.07 & 10 & 0.04 & 10 & 0.06 & 10 & 26\end{array}$

$\begin{array}{lllllll}0.50 & 2 & 0.41 & 2 & 0.46 & 2 & 8\end{array}$

$\begin{array}{lllllll}0.47 & 4 & 0.22 & 4 & 0.32 & 4 & 12\end{array}$

$\begin{array}{lllllll}0.53 & 1 & 0.30 & 3 & 0.40 & 3 & 11\end{array}$

$\begin{array}{lllllll}0.23 & 6 & 0.17 & 5 & 0.21 & 5 & 16\end{array}$

companies discloses information about seven subcategories, which are as follows: "problem solving capacity" under INC category, "loyalty" and "suppliers" under EXC category and "flexibility", "participation in the development of the company", "knowledge map" and "employees' satisfaction" under HC category.

Findings about the sub-categories of the INC demonstrate that disclosure ranking of each sub-category of INC for the bank, NBFI and combined disclosure score are not consistent. For instance, the ranking of "Research and Development" for banks is 2 with the score of 0.56 , whereas the ranking for NBFI is 5 with the score of 0.29 , and for combined is 4 . Similar inconsistent ranking can also be observed based on the results for "Innovations", "Technological infrastructure", "Technological investment:, "Other internally generated intangible assets" and "Communication systems", which suggests that banking sector and NBFI sector have different priorities in disclosing INC information in their annual report. 
The ranking of different sub-categories of EXC presented in Table 3 indicates, "Market value and Share price" and "Shareholders" are two mostly disclosed information subcategories for both the bank and NBFI. However, like the INC, ranking of other subcategories of EXC for both sectors is not consistent, except for the "Customer satisfaction", "Loyalty" and "Suppliers".

Table 3 shows that education level of workforce in an institution is the highest disclosed item under $\mathrm{HC}$, which has a mean value of 0.47 in combined ranking. However, "Employee development plan" is the top HC disclosing sub-category for the banking sector with the score of 0.53 , which, in fact, is the highest disclosure score among all the HC sub-categories for both of the sectors. These findings, thus, indicate the similar pattern of inconsistent priority by the banking sector and NBFI sector to disclose various sub-categories of ICD. In other words, the level of disclosure for different categories and sub-categories of IC is varied for the financial institutions of Bangladesh, which, indeed, initially seems to support $H 2$.

In summary, "Management philosophy" that includes vision and mission of an organization has got more attention and mostly disclosed issues by both banks and NBFIs. This finding is consistent with the prior study by Ousama and Fatima (2012) in the context of an emerging economy. Similar results can also be found in the study by Abhayawansa and Azim (2014) for listed pharmaceutical companies in Bangladesh. In contrast, none of the sample companies has disclosed information on seven subcategories, which are "Problemsolving capacity", "Loyalty", "Suppliers", "Flexibility", "Participation in the development of the company", "Knowledge map" and "Employees' satisfaction". Nevertheless, overall findings of this study conclude that organizations, including, banking and NBFIs have their own preference and priority while disclosing IC information in their annual reports, as also suggested by Slack and Munz (2016), which reflects that presentation of IC information in annual reports depends on organizational strategy and leadership guidance.

4.1.3 Frequency distribution of intellectual capital disclosures. The frequency distribution of the ICDI for sample banks, NBFI and combined financial institutions is presented in Table 4. The purpose of this frequency distribution is to analyze further for deeper insights about prior findings of low level of ICD by the listed financial institutions in Bangladesh. Results of overall sample companies show that the model class of ICDI is $26 \%-30 \%$ with the frequency of 15 companies, which indicates that maximum 15 companies (out of 53) or maximum $28 \%$ of sample companies are disclosing IC information at the level of $26 \%-30 \%$. On the other hand, only five sample financial institutions belong to the highest ICD class, i.e. $41 \%-45 \%$, which shows that the level of ICD of $9 \%$ of sample companies is more than $41 \%$ but less than $45 \%$. In addition, the overall results of cumulative frequency demonstrate that $83 \%$ of the financial institutions are disclosing less than $35 \%$ of the IC items in their annual

\begin{tabular}{|c|c|c|c|c|c|c|c|c|c|c|}
\hline Class & $\begin{array}{l}\text { No. } \\
\text { of Co. }\end{array}$ & $\begin{array}{l}\mathrm{Ov} \\
\% \\
\text { of Co. }\end{array}$ & $\begin{array}{l}\text { rerall } \\
\text { Cumulative }(\%)\end{array}$ & $\begin{array}{l}\text { No. } \\
\text { of Co. }\end{array}$ & $\begin{array}{l}\text { B } \\
\% \\
\text { of Co. }\end{array}$ & $\begin{array}{l}\text { ank } \\
\text { Cumulative (\%) }\end{array}$ & $\begin{array}{l}\text { No. } \\
\text { of Co. }\end{array}$ & $\begin{array}{c}\mathrm{N} \\
\% \\
\text { of Co. }\end{array}$ & $\begin{array}{l}\text { BFI } \\
\text { Cumulative }(\%)\end{array}$ & \\
\hline $0.11-0.15$ & 3 & 0.06 & 0.06 & 0 & 0.00 & 0.00 & 3 & 0.13 & 0.13 & \\
\hline $0.16-0.20$ & 9 & 0.17 & 0.23 & 2 & 0.07 & 0.07 & 7 & 0.30 & 0.43 & Table \\
\hline $0.21-0.25$ & 6 & 0.11 & 0.34 & 4 & 0.13 & 0.20 & 2 & 0.09 & 0.52 & 1 adie 4. \\
\hline $0.26-0.30$ & 15 & 0.28 & 0.62 & 8 & 0.27 & 0.47 & 7 & 0.30 & 0.83 & Frequency \\
\hline $0.31-0.35$ & 11 & 0.21 & 0.83 & 8 & 0.27 & 0.73 & 3 & 0.13 & 0.96 & distribution of \\
\hline $0.36-0.40$ & 4 & 0.08 & 0.91 & 4 & 0.13 & 0.87 & 0 & 0.00 & 0.96 & intellectual capital \\
\hline $0.41-0.45$ & 5 & 0.09 & 1.00 & 4 & 0.13 & 1.00 & 1 & 0.04 & 1.00 & disclosure index \\
\hline Total & 53 & 1.00 & - & 30.0 & 1.0 & - & 23 & 1.00 & - & (ICDI) \\
\hline
\end{tabular}

Intellectual capital disclosure practices

41 
PRR

5,1

reports, and remaining $17 \%$ of the companies have ICDI between the ranges of $36 \%$ and $45 \%$. Findings of banking sector and NBFI sector indicate that ICD level of $73 \%$ of sample banks is not more than $35 \%$, whereas $83 \%$ of NBFI discloses less than $30 \%$ of IC information. In brief, majority of the sample companies disclose less than $35 \%$ of IC items, and these results complement the prior findings of low level of ICD in the listed financial institutions of Bangladesh, which is consistent with the prior study by Birindelli et al. (2020) for the Italian banks. Therefore, these results reiterate and complement the prior support of HH1.

\subsection{Differences of intellectual capital disclosure practices by sector}

Table 5 presents independent sample $t$-test results of varied disclosure in IC information among banks and NBFIs under the broader category of ICDI and, particularly, INCDI, EXCDI and HCDI. As can be seen from the table, the significant level of $t$-test for ICDI ( $p$ value $=0.00$ ) is less than 0.01 , which suggests that banking sector and NBFI sector are significantly different in terms of extent of ICD and supports $H 3$. This finding complements the prior results of descriptive analysis presented in Table 2 , which indicates the higher level of ICD of banking sector than NBFI sector.

Further results of the $t$-test of the IC sub-categories demonstrate that $p$-values of the INCDI and HCDI are 0.00 and 0.02 , which are less than 0.01 and 0.05 , respectively, which suggests the significant differences between banking sector and NBIF sector in terms of INCD and HCD, and therefore supports $H 3 a$ and $H 3 c$. However, these two sectors are not significantly varied in terms of EXCD, because the $p$-value for the EXCDI of 0.59 is more than 0.05 . In brief, though banking sector and NBFI significantly differ in terms of overall ICD, these sectors are not significantly varying in terms of all the ICD sub-categories. However, overall significant result supports $H 3$ that banking sector and NBIF sector are varied in terms of the level of ICD. This finding is also consistent with the results of Striukova et al. (2008).

Results of Mann-Whitney U-test presented in Table 6 also indicate similar findings that $p$-values of ICDI, INCDI and HCDI are less than 0.05, but not for EXCDI. These findings provide the robustness of significant variation of ICD practices between banking sector and NBFI sector in Bangladesh, and complement the support of $H 3, H 3 a$ and $H 3 c$. These results are consistent with the prior study by Sharma and Dharni (2017) in an emerging economy that the level of ICD varied significantly across different sectors in terms of different categories of disclosures. Indeed, these results imply the sector specificity as well as disclosure-category specificity of ICD practices of financial institutions in Bangladesh.

\subsection{Differences of intellectual capital disclosure practices by intellectual capital disclosure categories}

The results of Friedman test used to examine the differences among three categories of ICD are presented in Table 7 . The test provides the $p$-value $(0.00)$ of less than 0.01 , which

Table 5.

Independent sample $t$-test results of ICD indices by sector

\begin{tabular}{lccccccc}
\hline \multicolumn{7}{l}{} & \multicolumn{2}{c}{ Mean } & & & \\
ICD indices & df & Bank & NBFI & Mean diff. & Std. error diff. & $t$-value & Sig. ( $p$-value) \\
\hline INCDI & 51 & 0.39 & 0.27 & 0.11 & 0.03 & 3.58 & 0.00 \\
EXCDI & 51 & 0.36 & 0.35 & 0.01 & 0.01 & 0.55 & 0.59 \\
HCDI & 51 & 0.20 & 0.14 & 0.06 & 0.02 & 2.40 & 0.02 \\
ICDI & 51 & 0.31 & 0.24 & 0.07 & 0.02 & 3.42 & 0.00 \\
\hline
\end{tabular}


indicates that variation among INCD, EXCD and HCD is significant. In other words, these results suggest that ICD practices of financial institutions are significantly different in terms of ICD categories. However, though these results of Friedman test indicate the significant difference among three ICD categories, the results restrict to investigate the specific variation of one ICD category with another category, e.g. the difference between INCD and EXCD or between INCD and HCD. The study, therefore, demands post hoc test, and applies another non-parametric test, namely, Wilcoxon test, to examine the differences of several arrangements between INCD-EXCD, INCD-HCD and EXCD-HCD. Table 8 presents Wilcoxon test results of each combination, which indicate a significant difference between $\operatorname{INCD}-H C D(Z=-6.134, p$ value $=0.00)$ and $\operatorname{EXCD}-H C D(Z=-6.311, p$ value $=0.00)$, whereas the difference of INCD-EXCD combination is found statistically insignificant $(Z=-1.12, p$ value $.26>0.05)$.

In summary, Friedman test shows that there is a statistically significant difference among three ICD categories, $\chi^{2}(2)=69.08, p$-value $=0.00$. Median values for the INCD, EXCD and HCD trial were $0.36(0.22-0.42), 0.36(0.32-0.41)$ and $0.14(0.11-0.23)$, respectively. Post hoc analysis with Wilcoxon tests is conducted with a Bonferroni correction applied, resulting in a significance level set at $p<0.017$. Though Friedman test shows the significant difference among three ICD categories, the post hoc analysis with Wilcoxon test specifies that there is no significant difference between INCD and EXCD. However, the overall findings complement the prior results of the current study, which highlights the variation of ICD practices of listed financial institutions of Bangladesh in terms of different ICD categories and their sub-categories as well, and support $H 2$.

\begin{tabular}{|c|c|c|c|c|c|c|}
\hline ICD indices & Sectors & $N$ & Mean rank & Sum of ranks & Sig. & \\
\hline \multirow[t]{2}{*}{ INCDI } & NBIF & 23 & 19.87 & 457.00 & \multirow[t]{2}{*}{0.00} & \\
\hline & Bank & 30 & 32.47 & 974.00 & & \\
\hline \multirow[t]{2}{*}{ EXCDI } & NBIF & 23 & 24.93 & 573.50 & \multirow[t]{2}{*}{0.37} & \\
\hline & Bank & 30 & 28.58 & 857.50 & & \\
\hline \multirow[t]{2}{*}{ HCDI } & NBIF & 23 & 20.98 & 482.50 & \multirow[t]{2}{*}{0.01} & $\begin{array}{r}\text { Table } 6 . \\
\text {. }\end{array}$ \\
\hline & Bank & 30 & 31.62 & 948.50 & & Mann-Whitney U- \\
\hline \multirow[t]{2}{*}{ ICDI } & NBIF & 23 & 19.50 & 448.50 & \multirow[t]{2}{*}{0.00} & test results of ICD \\
\hline & Bank & 30 & 32.75 & 982.50 & & indices by sector \\
\hline
\end{tabular}

\begin{tabular}{|c|c|c|c|c|c|c|c|c|}
\hline ICD indices & $N$ & 25th & $\begin{array}{l}\text { Percentiles } \\
\text { 50th (Median) }\end{array}$ & 75th & Chi-square & Df & Sig. & Table 7. \\
\hline INCDI & 53 & 0.22 & 0.36 & 0.42 & 69.08 & 2 & 0.00 & Results of Friedman \\
\hline EXCDI & 53 & 0.32 & 0.36 & 0.41 & & & & test by ICD \\
\hline HCDI & 53 & 0.11 & 0.14 & 0.23 & & & & categories \\
\hline
\end{tabular}

\begin{tabular}{|c|c|c|c|c|}
\hline Items & INCDI-EXCDI & INCDI-HCDI & EXCDI-HCDI & $\begin{array}{l}\text { Wilcoxon test results } \\
\text { by different }\end{array}$ \\
\hline$Z$ & -1.12 & -6.134 & -6.311 & combinations of ICD \\
\hline Sig. & 0.263 & 0.000 & 0.000 & \\
\hline
\end{tabular}

Intellectual capital disclosure practices

\begin{tabular}{r}
\hline \\
Table 6. \\
indices by sector \\
Mann-Whitney U-
\end{tabular}




\section{PRR}

5,1

\subsection{Comparison of intellectual capital disclosures with different prior studies}

Table 9 presents the comparative analysis of findings of current study with contemporary prior studies on ICD in the context of developing economic settings. The analysis finds some inconsistency in the results of current study with another prior study, by Khan and Ali (2010), on the banks in Bangladesh. For example, Khan and Ali (2010) found HCD as the highest ICD category with HCDI score $51 \%$ as compared to the $18 \%$ in the current study. In addition, this study finds EXCD and HCD as the highest and lowest ICD categories, respectively, as compared to the HCD and INCD, respectively, in the study by Khan and Ali (2010). Overall, ICDI also shows the inconsistency between these two studies, as $28 \%$ in current study compared to $29 \%$ in the prior one. Based on the comparative analysis in the table, three possible reasons for these inconsistencies of ICD by financial institutions in Bangladesh can be highlighted. First, these two studies use different number of ICD items, i.e. the current study considers in total 93 ICD items as compared to only 21 items by Khan and Ali (2010). Consequently, the result of $28 \%$ of 93 disclosure items in comparison with $29 \%$ of 21 items may indicate that the level of ICD is increasing over the period of time. Second, though the current study considers all of the 53 listed banks and NBFI, the prior one focused on only top 20 banks. Typically, the large companies have more incentives for higher level of disclosure to reduce their more complex agency conflicts as compared to smaller ones (Inchausti, 1997). Therefore, the possible differences of ICD by large companies and aggregate sample companies can be observed. Finally, the period of these studies may also create the differences as different crucial initiatives in capital market have been implemented in the recent past to ensure more transparency and accountability for corporate reporting in Bangladesh. For example, BSEC has revised its "Code of Corporate Governance" in 2012, incorporating more stringent provision, as compared to the prior code in 2006.

The results in the table further show that, like the study by Ousama and Fatima (2012) on non-financial listed companies in Malaysia, the current study finds EXC as the mostly disclosed ICD category. In contrast, another prior study by Bhatia and Mehrotra (2016) has identified the INC as the most popular ICD category among banks in India. The possible reasons of this contradictory result can be different economic settings and different number of state-owned banks in the sample set. In brief, the comparative analysis among these studies highlights five key factors as the possible reasons for the inconsistent results, such as sample companies from different sectors, companies with different sizes, different set of ICD items, different time series and different country contexts.

\section{Conclusions}

This study attempts to investigate the ICD practices of financial institutions in Bangladesh. The relevant data about 93 ICD items are collected from the annual reports of 53 listed financial institutions for the year 2014. The empirical findings of this research show that the level of ICD of the financial institutions in Bangladesh is very low as majority of the ICD items are not disclosed in annual reports of the companies. This empirical evidence is consistent with a prior study by Khan and Ali (2010). The low level of ICD can also be observed in the findings in the context of other emerging economies (Ousama and Fatima, 2012; Singh and Kansal, 2011). Results further show that EXC is the most disclosed IC category in the financial institutions, whereas $\mathrm{HC}$ is the least preferred, which reflects the undermining tendency of financial institutions of Bangladesh to consider human resources as its strategic assets. In addition, the results of different analyses indicate that the variation of level of disclosure among different IC categories is significant. These results suggest that financial institutions of Bangladesh do not have the same level of emphasis on the different ICD items and categories in disclosing IC information in their annual reports, which is consistent with findings of Slack and Munz (2016) 


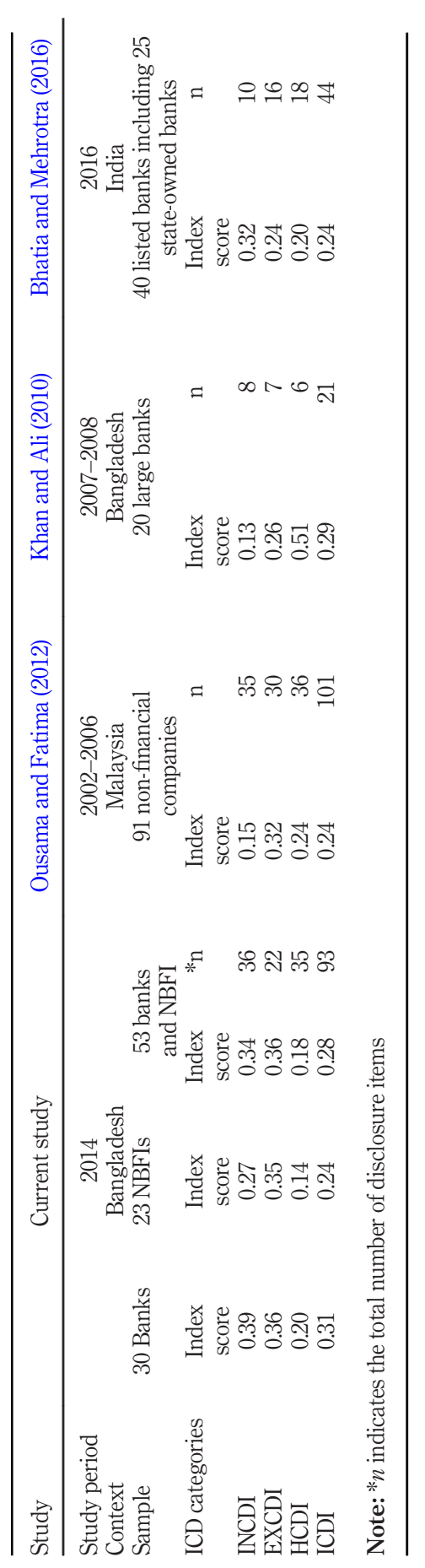

Intellectual capital disclosure practices

45

Table 9. Comparative analysis of ICDI of prior studies 
PRR

5,1

as well. The possible reason for these differences is that different companies may have different strategic priorities in disclosing IC information.

The findings on ICD of banks and NBIFs demonstrate that the level of ICD of banks is higher than NBFIs in terms of all IC categories, i.e. INC, EXC and HC. In addition, the results indicate that the variation of ICD practices between banks and NBIFs is statistically significant. These results suggest that sector of a company is an important determinant of ICD practices, which is consistent with prior findings of Bozzolan et al. (2006), Ousama et al. (2012) and Whiting and Woodcock (2011). However, though the knowledge-intensive companies such as technology and service sector companies expect to disclose more IC information because of their higher dependency on IC for value creation (Chen Goh, 2005; Kamath, 2007; Salamudin et al., 2010), this study indicates an interesting insight that financial institutions as services providing and knowledge-based companies are also varied in terms of ICD for their sub-sectors, i.e. banks and NBFIs. These results imply that companies belonging to different sectors of a knowledge-intensive industry can be varied to disclose IC information.

The current study has created some significant practical implications to corporate managers, policymakers and regulators. For example, results of this study assist them to enhance their understanding about the ICD practices. Based on this understanding, corporate policymakers can set appropriate strategy to develop IC and disseminate the information about IC, which, in turn, reduces the information asymmetry problems of companies. Bangladesh Bank, as the regulators, can apply the findings to rethink about exiting regulation to develop IC and to improve the level of ICD of financial institutions in Bangladesh which, indeed, may lead to the competitiveness and sustainability of these companies as well.

There are some important caveats required to be considered in interpreting results of this study. First, this study only focuses on listed banks and NBFIs and excludes insurance companies and other unlisted financial institutions in Bangladesh, which may limit the usability of the results of this study to generalize the ICD practices of overall financial industry. Second, because of considering only one-year ICD data, results of this study limit to explore the changes of ICD practices over the period. Therefore, further research may consider all the financial institutions in Bangladesh with multiple time periods for more comprehensive portrait of ICD practices. Moreover, the current study can be extended by investigating ICD practices of financial institutions from multiple countries with similar context, such as South Asian countries, for enhancing understanding of ICD practices from wider context.

\section{References}

Abeysekera, I. (2010), "The influence of board size on intellectual capital disclosure by Kenyan listed firms", Journal of Intellectual Capital, Vol. 11 No. 4, pp. 504-518.

Abeysekera, I. and Guthrie, J. (2005), "An empirical investigation of annual reporting trends of intellectual Capital in Sri Lanka", Critical Perspectives on Accounting, Vol. 16 No. 3, pp. 151-163.

Abhayawansa, S. and Azim, M. (2014), "Corporate reporting of intellectual capital: evidence from the bangladeshi pharmaceutical sector", Asian Review of Accounting, Vol. 22 No. 2, pp. 98-127.

Ahmed Haji, A. and Mohd Ghazali, N.A. (2013), "A longitudinal examination of intellectual capital disclosures and corporate governance attributes in Malaysia", Asian Review of Accounting, Vol. 21 No. 1, pp. 27-52, doi: 10.1108/13217341311316931.

April, K.A., Bosma, P. and Deglon, D.A. (2003), "IC measurement and reporting: Establishing a practice in SA mining", Journal of Intellectual Capital, Vol. 4 No. 2, pp. 165-180, doi: 10.1108/14691930310472794.

Atan, R. and Rahim, A. (2012), "Corporate reporting of intellectual capital: evidence from ace market of Bursa Malaysia”, 2012 IEEE Symposium on Humanities, Science and Engineering Research, doi:10.1109/shuser.2012.6268779. 
Beattie, V. and Thomson, S.J. (2007), "Lifting the lid on the use of content analysis to investigate intellectual capital disclosures", Accounting Forum, Vol. 31 No. 2, pp. 129-163.

Belal, A.R., Mazumder, M.M.M. and Ali, M. (2018), "Intellectual capital reporting practices in an islamic bank; a case study", Business Ethics: A European Review, Vol. 28 No. 2, pp. 1-15.

Bhatia, M. and Mehrotra, V. (2016), "Determinants of intellectual capital disclosure: evidence from Indian banking sector", South Asian Journal of Management, Vol. 23 No. 1, pp. 89-111.

Birindelli, G., Ferretti, P., Chiappini, H. and Cosentino, A. (2020), "Intellectual capital disclosure: some evidence from healthy and distressed banks in Italy", Sustainability, Vol. 12 No. 8.

Intellectual capital disclosure practices

Bismuth, A. and Tojo, Y. (2008), "Creating value from intellectual assets", Journal of Intellectual Capital, Vol. 9 No. 2, pp. 228-245, doi: 10.1108/14691930810870319.

Bollen, L., Vergauwen, P. and Schnieders, S. (2005), "Linking intellectual capital and intellectual property to company performance", Management Decision, Vol. 43 No. 9, pp. 1161-1185.

Bozzolan, S., Favotto, F. and Ricceri, F. (2003), "Italian annual intellectual capital disclosure: an empirical analysis”, Journal of Intellectual Capital, Vol. 4 No. 4, pp. 543-558.

Bozzolan, S., O'Regan, P. and Ricceri, F. (2006), "Intellectual capital disclosure (ICD)", Journal of Human Resource Costing and Accounting, Vol. 8 No. 2, pp. 57-72.

Brüggen, A., Vergauwen, P. and Dao, M. (2009), "Determinants of intellectual capital disclosure: evidence from Australia", Management Decision, Vol. 47 No. 2, pp. 233-245, doi: 10.1108/00251740910938894.

Burgman, R. and Roos, G. (2007), The importance of intellectual capital reporting: evidence and implications, Journal of Intellectual Capital, Vol. 8 No. 1, pp. 7-51, doi: 10.1108/14691930710715051.

Chen Goh, P. (2005), "Intellectual capital performance of commercial banks in Malaysia", Journal of Intellectual Capital, Vol. 6 No. 3, pp. 385-396, doi: 10.1108/14691930510611120.

Dey, P.K. and Faruq, M.O. (2019), "Determinants of intellectual capital disclosure: an investigation on DS30 firms in Bangladesh (August 30, 2019)", Asian Journal of Accounting Perspectives, Vol. 12 No. 2, pp. 27-48.

Dumay, J.C. (2012), "Grand theories as barriers to using IC concepts", Journal of Intellectual Capital, Vol. 13 No. 1, pp. 4-15.

Erik Sveiby, K. (1997), “The intangible assets monitor”, Journal of Human Resource Costing \& Accounting, Vol. 2 No. 1, pp. 73-97, doi: 10.1108/eb029036.

Ferreira, A.L., Branco, M.C. and Moreira, J.A. (2012), "Factors influencing intellectual capital disclosure by portuguese companies", International Journal of Accounting and Financial Reporting, Vol. 2 No. 2, p. 278 .

Gray, R. (2013), "Lifting the lid on the use of content analysis to investigate intellectual capital disclosures", Social and Environmental Accountability Journal, Vol. 33 No. 1, pp. 56-56.

Grojer, J.E. and Johanson, U. (1999), "Voluntary guidelines on the disclosure of intangibles: a bridge over troubled water?", Journal of Intellectual Capital, Vol. 14 No. 4, pp. 423-436.

Guthrie, J., Ricceri, F. and Dumay, J. (2012), "Reflections and projections: a decade of intellectual capital accounting research", The British Accounting Review, Vol. 44 No. 2, pp. 68-82.

Guthrie, J., Petty, R. and Ricceri, F. (2006), "The voluntary reporting of intellectual capital”, Journal of Intellectual Capital, Vol. 7 No. 2, pp. 254-271, doi: 10.1108/14691930610661890.

Guthrie, J., Petty, R., Yongvanich, K. and Ricceri, F. (2004), "Using content analysis as a research method to inquire into intellectual capital reporting", Journal of Intellectual Capital, Vol. 5 No. 2, pp. 282-293, doi: 10.1108/14691930410533704.

Hunter, L., Webster, E. and Wyatt, A. (2005), "Measuring intangible capital: a review of current practice", Australian Accounting Review, Vol. 15 No. 36, pp. 4-21.

Inchausti, B.G. (1997), "The influence of company characteristics and accounting regulation on information disclosed by Spanish firms", European Accounting Review, Vol. 6 No. 1, pp. 45-68, doi: 10.1080/096381897336863. 
PRR

5,1

Johanson, U. (2003), "Why are capital market actors ambivalent to information about certain indicators on intellectual capital?”, Accounting, Auditing \& Accountability Journal, Vol. 16 No. 1, pp. 31-38, doi: $10.1108 / 09513570310464255$.

Khan, H.U.Z. and Ali, M. (2010), "An empirical investigation and users' perceptions on intellectual Capital reporting in banks: evidence from Bangladesh", Journal of Human Resource Costing and Accounting, Vol. 14 No. 1, pp. 48-69.

Lambert, R.A. (1998), "Customer satisfaction and future financial performance. Discussion of: are nonfinancial measures leading indicators of financial performance? An analysis of customer satisfaction”, Journal of Accounting Research, Vol. 36, pp. 37-46.

Li, J., Pike, R. and Haniffa, R. (2008), "Intellectual capital disclosure and corporate governance structure in UK firms", Accounting and Business Research, Vol. 38 No. 2, pp. 137-159.

McPhail, K. (2009), "Where is the ethical knowledge in the knowledge economy? Power and potential in the emergence of ethical knowledge as a component of intellectual capital", Critical Perspectives on Accounting, Vol. 20 No. 7, pp. 804-822.

Nurunnabi, M. and Hossain, M. (2011), "Intellectual capital reporting in a South Asian country: evidence from Bangladesh", Journal of Human Resource Costing and Accounting, Vol. 15 No. 3, pp. 196-233.

Oliveira, L., Lima Rodrigues, L. and Craig, R. (2010), "Intellectual capital reporting in sustainability reports", Journal of Intellectual Capital, Vol. 11 No. 4, pp. 575-594, doi: 10.1108/14691931011085696.

Ordonez de Pablos, P. (2005), "Intellectual capital reports in India: lessons from a case study", Journal of Intellectual Capital, Vol. 6 No. 1, pp. 141-149.

Ousama, A.A. and Fatima, A.H. (2012), "Extent and trend of intellectual capital reporting in Malaysia", International Journal of Managerial and Financial Accounting, Vol. 4 No. 2, pp. 159-176.

Ousama, A.A., Fatima, A.H. and Hafiz Majdi, A.R. (2011), "Effects of intellectual capital disclosed in annual reports on market capitalization: evidence from busra Malaysia”, Journal of Human Resource Accounting and Costing, Vol. 15 No. 2, pp. 85-101.

Ousama, A.A., Fatima, A.H. and Rashid Hafiz-Majdi, A. (2012), "Determinants of intellectual capital reporting: evidence from annual reports of malaysian listed companies", Journal of Accounting in Emerging Economies, Vol. 2 No. 2, pp. 119-139.

Petty, R. and Cuganesan, S. (2005), "Voluntary disclosure of intellectual capital by Hong Kong companies: examining size, industry and growth effects over time", Australian Accounting Review, Vol. 15 No. 36, p. 40.

Petty, R., Cuganesan, S., Finch, N. and Ford, G. (2009), "Intellectual capital and valuation: challenges in the voluntary disclosure of value drivers", SSRN Electronic Journal, doi: doi:10.2139/ ssrn. 1490208 .

Rahman, M.M., Sobhan, R. and Islam, M.S. (2019), "Intellectual capital disclosure and its determinants: empirical evidence from listed pharmaceutical and chemical industry of Bangladesh", Journal of Business Economics and Environmental Studies, Vol. 9 No. 2, pp. 35-46.

Roos, J., Edvinsson, L. and Dragonetti, N.C. (1997), Intellectual Capital: Navigating the New Business Landscape, Springer.

Salamudin, N., Bakar, R., Kamil Ibrahim, M. and Haji Hassan, F. (2010), "Intangible assets valuation in the malaysian capital market", Journal of Intellectual Capital, Vol. 11 No. 3, pp. 391-405.

Sharma, S. and Dharni, K. (2017), "Intellectual capital disclosures in an emerging economy: status and trends", Journal of Intellectual Capital, Vol. 18 No. 4, pp. 868-883.

Singh, S. and Kansal, M. (2011), "Voluntary disclosures of intellectual capital: an empirical analysis", Journal of Intellectual Capital, Vol. 12 No. 2, pp. 301-318.

Slack, R. and Munz, M. (2016), "Intellectual capital reporting, leadership and strategic change", Journal of Applied Accounting Research, Vol. 17 No. 1, pp. 61-83. 
Soon Yau, F., Sin Chun, L. and Balaraman, R. (2009), "Intellectual capital reporting and corporate characteristics of public-listed companies in Malaysia", Journal of Financial Reporting and Accounting, Vol. 7 No. 1, pp. 17-35, doi: 10.1108/19852510980000639.

Stewart, T.A. (1997), Intellectual Capital: The New Wealth of Nations, New York, NY.

Striukova, L., Unerman, J. and Guthrie, J. (2008), "Corporate reporting of intellectual capital: evidence from UK companies", The British Accounting Review, Vol. 40 No. 4, pp. 297-313.

Van der Meer-Kooistra, J. and Zijlstra, S.M. (2001), "Reporting on intellectual capital", Accounting, Auditing and Accountability Journal, Vol. 14 No. 4, pp. 456-476.

Intellectual capital disclosure practices

Wagiciengo, M.M. and Belal, A.R. (2012), "Intellectual capital disclosures by South African companies: a longitudinal investigation", Advances in Accounting, Vol. 28 No. 1, pp. 111-119.

White, G., Lee, A. and Tower, G. (2007), "Drivers of voluntary intellectual capital disclosure in listed biotechnology companies", Journal of Intellectual Capital, Vol. 8 No. 3, pp. 517-537.

Whiting, R.H. and Woodcock, J. (2011), "Firm characteristics and intellectual capital disclosure by australian companies", Journal of Human Resource Costing and Accounting, Vol. 15 No. 2, pp. 102-126.

\section{Further reading}

AbdolMohammadi, M.J. (2005), "Intellectual capital disclosure and market capitalization", Journal of Intellectual Capital, Vol. 6 No. 3, pp. 397-416.

Abeysekera, I. (2006), "Managing human capital in a privately owned public hotel chain”, International Journal of Hospitality Management, Vol. 25 No. 4, pp. 586-601.

Abeysekera, I. (2011), "Further evidence of critical thinking and final examination performance in advanced financial accounting", Accounting Education, Vol. 20 No. 1, pp.1-18.

Branswijck, D. and Everaert, P. (2012), "Intellectual capital disclosure commitment: myth or reality?", Journal of Intellectual Capital, Vol. 13 No. 1, pp. 39-56.

Campbell, D. and Rahman, M.R.A. (2010), "A longitudinal examination of intellectual capital reporting in marks and spencer annual reports, 1978-2008”, The British Accounting Review, Vol. 42 No. 1, pp. 56-70.

Cerbioni, F. and Parbonetti, A. (2007), "Exploring the effects of corporate governance on intellectual capital disclosure: an analysis of European biotechnology companies", European Accounting Review, Vol. 16 No. 4, pp. 791-826.

Edvinsson, L. and Malone, M.S. (1997), "Intellectual capital: realizing your company’s true value by finding its hidden brainpower".

Jayasooriya, S. (n.d.), "An empirical investigation of intellectual capital disclosure practices among listed companies in Sri Lanka”, doi: 10.31357/fmscmst.2011.00211.

Lang, M. and Lundholm, R. (1996), "Corporate disclosure policy and analyst behavior", Accounting Review, pp. 467-491.

Orens, R., Aerts, W. and Lybaert, N. (2009), "Intellectual capital disclosure, cost of finance and firm value", Management Decision, Vol. 47 No. 10, pp. 1536-1554.

Petty, R. and Guthrie, J. (2000), "Intellectual capital literature review: measurement, reporting and management", Journal of Intellectual Capital, Vol. 1 No. 2, pp. 155-176.

Ricceri, F. (2008), Intellectual Capital and Knowledge Management: Strategic Management of Knowledge Resources, Routledge.

Vergauwen, P.G. and Van Alem, F.J. (2005), “Annual report IC disclosures in The Netherlands, France and Germany”, Journal of Intellectual Capital, Vol. 6 No. 1, pp. 89-104. 
PRR

5,1

50

\section{Appendix}

No. Intellectual capital disclosure items

Internal capital (INC)

1. $\quad$ 1.1. Innovations

a) Information about products or services (e.g. number, type, others)

b) Information about new products or services launched into the market during the financial year

$\begin{array}{ll}2 . & \text { b) } \% \text { of new products or services to total no. of products or services }\end{array}$

4. 1.2. Technological infrastructure:

a) Quantitative/qualitative information about PCs and laptops (e.g. total no./per office/per employee)

5. b) Information about software and programmes available in the company (e.g. in use/upgraded)

6. c) Information about databases which the company can access

7. d) Information about the company's website (e.g. existence of website/maintenance/upgrade/ others)

8. e) Information about availability of networks/internet/cable TV

$9 . \quad$ f) Expenditure on purchase of PCs and other related technological infrastructure

10. g) Expenditure of upgrading and maintaining of the technological infrastructure (e.g. software/ PCs/others)

11. 1.3. Technology investments

a) $\%$ or ratios of total investment in IT to, e.g. turnover/total costs/total expenditure/others

12. b) Information about other technology investments

13. c) IT expenditure (investment)

14. 1.4. Research and development (R\&D)

a) Information about research and development

15. b) Information about the capitalized development expenditure during the financial year (e.g. recognition criteria/useful lives/amortization rates and methods/others)

16. c) Carrying amount or reconciliation of the carrying amount of the capitalized development expenditure

17. d) Gross carrying amount and the accumulated amortization of capitalized development expenditure

18. e) Amortization amount of the capitalized development expenditure for the financial year

19. f) Aggregate amount of R\&D expenditure (recognized as an expense or written off during financial year)

20. g) $\%$ or ratios of total expenditure of R\&D to, e.g. turnover/total costs/total expenditure/others

21. 1.5. Other internally generated intangible assets

a) Information about other internally generated intangible assets (e.g. goodwill/brand names/ copyrights/patents and other industrial) property rights/ service and operating rights/designs and prototypes/others)

22. 1.6. Quality

1.6. Quality
a) Information about awards and quality certifications (e.g. ISO certifications, others)

23. b) Information about a unit (e.g. committee/department) that ensures quality of products or services

24. c) $\%$ or ratios of annual cost of quality management to, e.g. total costs/total expenditure/others

$25 . \quad$ d) No. or $\%$ of complaints (claims)

26. e) Information about employees involved in quality management (e.g. no./\%/others)

Table A1.

27.

f) Total cost of quality management

28. 1.7. Communication systems

a) Information about the availability of internal magazines/newsletters/circulars categories used in this study 
No. Intellectual capital disclosure items

29. b)Information about presentations/workshops, the availability of discussion forum/presentation/ workshops

30. c) Information about the availability of other communication facilities (e.g. videos/Web cam/ voicemail/teleconference/multimedia facilities/e-mail)

31. 1.8. Processes

a) Information about the management processes

$32 . \quad$ b) Information about the technological processes

33. c) Information about identified critical processes during the financial year (e.g. \%/no.)

34. d) \% or ratios of administrative expenditure to, e.g. turnover/total costs/total expenditure/no. of employees/others

35. 1.9. Problem solving capacity

a) Average time to solve the problem/standard response time to complaints

36. 1.10. Management philosophy

ac Information about the company's vision and mission

External capital (EXC)

37. 2.1. Business partnering and alliances agreements

a) Information about alliances or co-operation with others (e.g. universities/research institutions/ other companies/governmental bodies)

38. b) Information about licensing/franchising agreements

39. 2.4. Loyalty

a) \% or no. of long-term customers (e.g. five or more years of relationship)

40. b) Average length (in years) of relationships with the company customers

41. 2.5. Customers'satisfaction

a) Information about enquiry on customers' satisfaction (e.g. customer survey or index/customer feedback/customers' complaints/after-service evaluation)

42. b) Cost of enquiring about customers' satisfaction

43. 2.6. Customers

a) No. of customers/information about market share

44. b) Information about major customers (e.g. main/big 5/big 10)

45. c) Information about new big customers/loss of big customers during the financial year

46. 2.7. Suppliers

a) No. of suppliers

47. b) Information about major suppliers (e.g. main/big 5/big 10)

48. c) Information about new big suppliers/loss of big suppliers during the financial year

49. 2.8. Marketing

a) $\%$ or ratios of marketing expenditure to, e.g. turnover/total costs/others

50. b) Marketing/distributing/selling expenditure

51. 2.9. Turnover and distribution channels

a) Information about distribution channels (e.g. commercial centres/sales hubs/new channels)

52 b) \% or ratios of total turnover in accordance to, e.g. line of business/product/customer/ distribution channel/others

53. 2.10. Market value and share price

a) Market value/market capitalization (e.g. yearly)

$54 . \quad$ b) Market share price highlight (e.g. daily/monthly/yearly)

55. c) Book value per share/earnings per share (e.g. basic, diluted)/price to earnings ratio

56. 2.11. Shareholders

a) No. of shareholders

$57 . \quad$ b) $\%$ of foreign/local shareholders/others

58. c) List of top shareholders (e.g. top 10/top 20/top 30) or list of significant shareholders (e.g. who own more than $5 \% / 10 \%$ of total shares) 


\section{PRR}

5,1
No. Intellectual capital disclosure items

\section{Human capital (HC)}

59. 3.1. Gender of employees

a) No. or $\%$ of men and wmen employees

60. 3.2. Age of the employees

a) Age of the employees (e.g. top managers/middle managers/others)

61. b) Distribution of the age of the employees (e.g. top managers/middle managers/others)

62. 3.3. Education level

a) No. or $\%$ or average of employees (e.g. top managers/middle managers/others) with professional qualifications/university/secondary school/primary school/other education

63. 3.4. Flexibility

a) No. or $\%$ of employees with non-normal working hours (e.g. part time/temporary/after hours/ teleworks or working from home)

64. b) Cost of non-normal working hours employees

65. 3.5. Employees' welfare

a) Information about policy of share scheme/share options scheme to employees

66. b) No. or \% of the shares held by different categories of employees (e.g. top managers/middle managers/others)

67. 3.6. Training and education

a) No. or $\%$ of employees (e.g. top managers/middle managers/others) that received training during the financial year

68. b) Total number of training courses/programmes for employees

69. c) \% or average training courses/programmes for employees per day/hours/others

70. d) $\%$ or ratios on training cost to, e.g. total cost/total employees cost/others

71. e) No. or \% of training courses provided by inside expert employees/outside experts

72. f) Information about training courses (e.g. name of training course, aim of the course, other information)

73. g) No. or \% or average of employees (e.g. top managers/middle managers/others) who received further education sponsored by the company during the financial year

74. h) $\%$ or ratios on education cost to, e.g. total cost/total employees cost/others

75. i) Information about further education programmes sponsored by the company during the financial year (e.g. name of programme/other information)

76. j) Training cost (e.g. total cost/per employee/for top managers/for middle managers/for other employees)

77. k) Education cost (e.g. total cost/per employee/per programme/for top managers/for middle managers/for other employees/others)

78. 3.7. Participation in the development of the company

a) Information about new ideas or suggestions by employees

79. b) Information about ideas or suggestions actually put into practice

80. c) Recompense or budget devoted to foster and reward employees' ideas or suggestions that were put into practice

81. 3.8. Knowledge map

a) Information about the existence of a catalogue of employees' knowledge (e.g. description of who knows what/know-how)

82. b) Cost of constructing and maintaining a knowledge map

83. 3.9. Employees' satisfaction

a) Information about enquiry on employees' satisfaction (e.g. employees index/employees feedback/employees' complaints)

84. b) Cost of enquiring about employees' satisfaction

85. 3.10. Employees' evaluation

a) Information about the existence of evaluation procedures 
No. Intellectual capital disclosure items

86. b) No. or \% of evaluated employees (e.g. based on top managers/middle managers/others)

87. 3.11. Distribution of employees

a) Total no. of employees

88. b) No. or \% of permanent and temporary employees

89. c) No. or \% of managers (e.g. top managers/middle managers/lower level managers)

90. d) No. or \% of employees in every department (e.g. production/sales and marketing/IT department/R\&D/administration)

91. 3.12. Employees' capacities and abilities

a) Information about employees (e.g. top managers, middle managers, others) who are high potential/outstanding/high caliber/expert/skilled (e.g. in terms of no. or average of professional experience)

92. 3.13. Employee development plans

a) Information about development plan for employees

93. 3.14. Safety and health of employees

a) Information about the safety and health

Table A1.

\section{Corresponding author}

Syed Abdulla Mamun can be contacted at:dr.saam12@gmail.com

For instructions on how to order reprints of this article, please visit our website: 